DOI: https://doi.org/10.24144/2409-6857.2018.2(52).144-156

УДК 338.22.021.1

Черленяк І.І., Проскура В.Ф., Шелемба М.М.

\title{
ТЕХНОЛОГІЧНІ ВИКЛИКИ ІНДУСТРІЇ .0 ТА ІНСТРУМЕНТИ ПРОМИСЛОВОЇ ПОЛІТИКИ: АНАЛІЗ ДОСВІДУ ПІВДЕННОЇ КОРЁ̈
}

\begin{abstract}
Розглянуто актуальну проблему запровадження в практику діяльності вітчизняних фірм та галузей промисловості технологічних новачій. На основі компаративістського аналізу фактичного матеріалу встановлено, щзо причиною стрімкого розвитку Південної Кореї була вдала промислова та економічна політика дирижизму спрямована на запровадження системи трансферу технологій. Авторами показано, щุо основа промислового успіху Південної Кореї в тому, щчо прибутки, отримані від запровадження залучених із зовні інноваџій спрямовувалися насамперед на розвиток науки, освіти та інноваційних галузей. Це дало можливість краӥні створити виробництво власних прибуткових технологічних, виробничих $i$ економічних інновачій.

Методами компаративістики виявлено причини гальмування інноваційної системи промисловості України. Зроблено висновки про необхідність проведення змін у суспільно-економічних відносинах у «виробничому трикутнику» капітал-прачя-інтелект. Запропоновано створення міністерства інноваційного розвитку та промислової політики.
\end{abstract}

Ключові слова: інновачї, інноваційний процес, промислова політика, економічна політика Південної Кореї, політика дирижизму, міністерство інноваційного розвитку та промислової політики.

Загальна постановка проблеми. Експерти сфери управління, економіки та бізнесу розвинутих країн світу інтенсивно обговорюють перспективи та виклики розгортання четвертої промислової революції (Індустрія 4.0). Моделюють їі вплив на глобальну економіку та регіональні економіки. Разом з тим, і міжнародні, і вітчизняні експерти відмічають катастрофічне відставання України в цьому напрямку. «У цьому масштабному глобальному переході ми знаходимося у початковій фазі, але він вже робить абсолютну більшість країн світу своєрідними«перехідними економіками» - не в прийнятому в 1990-х роках смислі (перехід до ринкової економіки), а в смислі формування якісно нової структури економіки. Ці зміни не $\epsilon$ однакові можливості та гарантії успіху. Цей перехідний процес породжує величезні виклики для всіх без винятку країн світу i, скоріш за все, призведе до деградації неефективних, неіінова-

(C) Черленяк Іван Іванович, доктор наук з державного управління, проф., завідувач кафедри бізнесадміністрування, маркетингу та менеджменту, ДВНЗ «Ужгородський національний університет», м. Ужгород, тел.+380993019642,

Проскура Володимир Федорович, д.е.н., проф, завідувач кафедри менеджменту та управління економічними процесами, Мукачівський державний університет, Україна, Тел.. +380555336707

Шелемба Марта Михайлівна, аспірантка кафедри політології і державного управління, ДВНЗ «Ужгородський національний університет», м. Ужгород, тел.+380950347216 ційних економік, не здатних знайти відповіді на ці виклики» [8].

В експертному середовищі складається враження, що замість руху до нового індустріального стану економіки, Україна, на жаль, свідомо стала на шлях зворотного напрямку - деіндустріалізації. Зокрема, про це свідчить факт, що в українському уряді підготували проект закону про приватизацію, за яким 893 державних підприємства мають бути приватизовані, а 1255 підприємств мають бути ліквідовані [9]. Зокрема, фактично депресовано флагман вітчизняного авіапрому концерн «Антонов», закрито єдиний в Україні факультет авіаційних та космічних систем Київського політехнічного інституту. Цей перелік руйнівних кроків «модернізації» економіки України, на жаль, можна продовжити. «Невидима рука» капіталізму та капіталістів спрямовує Українську економіку у русло відстаючих країн третього світу. «Невидима рука» підштовхує нас на розпорошення інтелектуального багатства нації, фактично примушує вітчизняних науковців різних галузей реалізовувати свої наукові доробки та надбання на користь закордонних лабораторій та концернів. Примушує найбільш інтелектуально конкурентоспроможних представників покоління, що вступає у відтворення економіки розкривати свої таланти у закордонних навчальних закладах, на таких засадах, при яких надалі будуть збагачувати економіку інших держав. У результаті, кваліфіковані фахівці 
різних галузей, отримавши освіту в Україні за рахунок нашого ВВП, плідно працюють на розвиток наших закордонних конкурентів.

Імпортні товари, супермаркети іноземної резидентури заполонили Україну: складається враження, що наша «перехідна» кономіка вже майже нічого власного не продукує. Проте, ця перехідна за безцінь активно «поставляє» сировинні та людські ресурси до економічно розвинутих країн. До того ж, Україна активно непрямо інвестує економіки інших країн широко споживаючи закордонні товари некритичного імпорту, тобто, товари які сама спроможна виробляти. Часто, навіть більш високої якості. Яка роль буде відводитися нашій країні, народу та державі за такої економічної та промислової політики у міжнародному поділі праці та розподілі доходів? Що потрібно зробити щоб не втратити останні фрагменти нашої наукової, освітньої та економічної незалежності? Ці питання гостро стоять уже не один рік перед Урядом та експертами з управління та економіки. Вони потребують якомога швидшого вирішення, що власне і обумовлює актуальність нашого дослідження.

Аналіз останніх досліджень і публікацій. Науково-теоретичні основи розбудови вітчизняної інноваційної інфраструктури сформовані такими вченими, як: О. І. Амоша, В. М. Геєць, С. С. Годунова, В. П. Ільчук, І. О. Іртищева, А. І. Сидорова, В. П. Семиноженко, В. П. Соловйов, М.Г. Чумаченко та інші. Проблематика промислової політики України розроблялася в роботах Ю.В.Кіндзерського, М.І. Зверяковова, О.А. Мельниченка, А.О.Задої та інших. В роботах згаданих авторів розроблялися і теоретичні, i практичні аспекти розвитку інноваційної складової промислового виробництва України. Незважаючи на проведені згаданими науковцями дослідження та розробки, в Україні на даний час відсутня дієва сучасна промислова політика. Ще не сформована критична маса «доказової бази» аргументів, здатна спонукати Уряд, крупний бізнес та інших відповідальних перед суспільством осіб впроваджувати модель інноваційного промислового розвитку. Потребує подальшого моделювання інноваційна інфраструктура трансферту технологій. Доцільно проаналізувати у цьому фокусі досвід країн, що досягли в цій сфері високих результатів а оцінити можливі альтернативи руху за лідерами.

Почнемо 3 того, що за Глобальним інноваційним індексом (GII) Україна вже далека від лідерів. Це при тому, що в перші роки незалежності вітчизняний науково-технічний потенціал (в межах УРСР) був один з найвищих у
Європі. При належному використанні зазначений рівень розвитку міг вивести нашу економіку до десятки лідерів країн світу за більшістю індексних систем оцінювання (GCI, GII, KOF). Проблема відновлення промислового потенціалу України на інноваційній основі зараз стоїть особливо гостро, так як окремі вітчизняні компрадорські бізнес-кола, усе ще намагаються спрямувати вектор розвитку економіки у напрямку протилежному до інноваційного, тобто до економіки сировинно-енергетичного придатку розвинутих країн. Підприємства, які здійснили витрати на новітне обладнання та інноваційні технології фактично не можуть виграти тендери на державні замовлення: собівартість їхньої продукції, а, відповідно, і відпускної ціни, у зв'язку із витратами на інновації, є тимчасово вищими, ніж у інших підприємств. 3 огляду на це, невирішеним завданням $\epsilon$ розробка концептуальної та емпіричної основи дієвих державних програм та конкретних заходів спрямованих на відновлення науково технічної могутності України в контексті викликів четвертої індустріальної революції. Для вирішення цієї проблеми можна звернутися до досвіду побудови промислової політики Південної Кореї, стрімкий розвиток якої почався за умов, гірших за ті, які мала Україна на старті виборювання державної незалежності.

Формулювання цілей статті. Метою дослідження $\epsilon$ вивчення кращих положень досвіду промислової політики Південної Кореї та виявлення можливостей його адаптації до умов України. Зважаючи на зміст мети статті нами було сформульовано основні завдання дослідження, а саме:

- визначити ключові проблемні аспекти розвитку промисловості України та окреслити причини їх появи;

- провести дослідження досвіду промислової політики Південної Кореї та виявити можливості його адаптації до умов України.

Опис основного матеріалу дослідження. У випадку сучасної України 3 економікою «наздоганяючої модернізації» індустріальний розвиток немов повністю переривається катастрофічним постіндустріальним «переходом». 10]. Ця обставина безперечно гальмує цивілізаційний розвиток економіки та суспільства України: для інновацій в технології не вистачає ні коштів, ні стимулів, ні мотивацій. Розвиток секторів економіки України у руслі парадигми Четвертої індустріальної революції, потребує вкладання до економіки значних коштів. Це обумовлено тим, що необхідно: виробляти нові технології та засоби виробництва кардинально нової якості; об'єднати в єдину 
систему автоматизоване виробництва та цифрові технології; забезпечити ефективне виробництво та використання кіберфізичних систем, запровадити глобальний розвиток Інтернету речей, Інтернету послуг тощо.

В глобальному вимірі базою для старту цього етапу стали новітні технологічні розробки провідних фірм світу та зміна організаційного дизайну економічно та технологічно розвинених країн G7. Тобто, нові індустріальні та постіндустріальні здобутки високо розвинутих індустріальних країн. Можна відзначити, що на сучасному етапі, на жаль, відбувається «пропаганда» положення про те, що новий етап розвитку України є природно неминучою стадією деіндустріалізації. $\mathrm{y}$ розвинутому капіталістичному світі ж насправді відбувається діалектичне та синергетичне продовження спіралі індустріалізації. А в Україні під гаслом «істин ринкового фундаменталізму», до того ж використаних для ідеологічного прикриття злочинів перерозподілу та привласнення фрагментів національного багатства, протягом останніх трьох десятиліть бездумно та бездушно (проте на диво цілеспрямовано) зацікавленими політичними та економічними агентами впливу «проведена» примітивна деіндустріалізація. Втрата промислового потенціалу відкинула нашу економіку, технології, рівень життя, конкурентоспроможні науку та освіту на багато років назад. Як наслідок, становище господарської системи України, як і аналогічних систем країн наздоганяючої модернізації, характеризується як складне кризове.

Новий тип особливо тяжкої кризи ідентифікується як трансформаційна криза. Варто далі розглянути раціональні альтернативи подолання цієї трансформаційної кризи. На нашу думку, на сучасному етапі тільки інноваційне підприємництво та нова індустріалізація може стати одним 3 основних напрямків подолання трансформаційної кризи. Саме вони здатні створити в Україні зачатки формування економічного росту за рахунок природного рівноправного міжнародного процесу обміну інноваціями та технологіями. Вони ж здатні підготувати Україні більш вигідні умови змагання за право бути у середовищі рівноправних учасників Четвертої індустріальної революції. Але інноваційне підприємництво може бути лише одним із стержнів комплексної системи суспільних та державних зусиль подолання кризи. У сучасному світі, інноваційне підприємництво це поширений вид комерційної діяльності, метою якої $\epsilon$ отримання прибутку шляхом створення i активного поширення інновацій в національній та світовій економіці. Цей вид діяльності, як свідчить досвід, не терпить як кумівства та розпилу бюджету для бізнесменів псевдоінноваторів [1; 6], так і байдужого ставлення урядових інституцій та банківського сектору.

Кроки економічних та технологічних змін можуть бути послідовно-дрібними, а можуть мати і вигляд «стрибків». Але, це стрибок тільки для зовнішніх спостерігачів. Як правило, ми помічаємо «стрибок» - результат, не задумуючись над тим, скільки підготовчих цілеспрямованих свідомих дрібних кроків потрібно було здійснити, щоб стрибок відбувся. Адже, не завжди в ірреальній економіці спрацьовує об'єктивний філософський закон «автоматичного» переростання кількісних змін у якісні.

Як показує досвід технологічно розвинених країн Азії, вагомі досягнення в розвитку пов'язані 3 впровадженням реально ефективної, грунтовної та відповідальної економічної політики держави. При цьому, для реалізації цієї політики потрібно щоб кожна 3 вказаних іiі характеристик не була формально задекларованою, а відповідала фактичному стану орієнтирів економічного розвитку країни. Усі «стрибки», що зробили країни Азії, які отримали назву «Азійські тигри», на схилі глобальної індустріальної фази базувалися на активній та відповідальній промисловій політиці. До «Азійських тигрів» у першу чергу належить Республіка Південна Корея. Досвід іiї економічного «стрибка» цікавий для України саме тим, що держава ефективно долучалася до регулювання та стимулювання розвитку інноваційної сфери. Цим забезпечувався цілеспрямований трансфер технологій, що поступово сформував основи ефективної промислової політики i наступної постіндустріальної епохи.

В історичній ретроспективі починаючи $360-\mathrm{x}$ років минулого століття Республіка Корея почала поступово розвивати свій інноваційний та індустріальний потенціал. Нагадаємо, що у 80тих роках промисловий потенціал УРСР суттєво перевищував потенціал Південної Кореї. А в кінці 1990-х на початку 2000-х глобальний інноваційний індекс України та Південної Кореї був приблизно на одному рівні. 3 плином часу в Кореї він і надалі зростав, а от в Україні навпаки - знижувався.

Причиною стрімкого розвитку Південної Кореї, на наш погляд, $є$ економічна політика, що $\epsilon$ варіацією політики дирижизму (Ф. Перру, М. Алле) сфокусованого на підходах до інноваційного процесу та трансферу технологій. Власне ідеологія дирижизму дала можливість кільком послідовно заміненим Урядам Південної Кореї започаткувати та планомірно посилювати таку промислову політику, де мало місце 
«конкурентне програмування», що грунтується на поєднанні державного планування розвитку секторів економіки та мотивування конкуренції приватних фірм.

В Україні ж навпаки, починаючи 3 середини 90-х років минулого століття державні інституції все більше ухилялися від процесу управління розвитком реальної економіки та промисловості, прикриваючись «демократичними» гаслом «свободи ринку». Стосовно цих гасел, зауважимо, що тільки економічні здобутки спрямовані на покращення добробуту народу свідчать про реальність демократії та ефективність економічної політики Уряду.

В сучасному світі для оцінювання економічних здобутків країн ефективно використовуються індексні методики. Зокрема, на міжнародному рівні ефективно використовується інтегральна оцінка стану розвитку інноваційної системи. Глобальний інноваційний індекс (GII) у 2017 p. охоплював 127 економік світу i використовував 81 показник. Складові показники цього індексу об'єднані у 7 розділів: Інститути (Institute), Людський капітал i дослідження (Human capital \& research), Інфраструктура (Infrastructure), Розвиток внутрішнього ринку (Market sophistication), Розвиток технологій та економіки знань (Knowledge \& technology outputs), Результати креативної діяльності (Creative outputs), Розвиток бізнесу (Business sophistication).

У 2017 році за глобальним інноваційним індексом (GII) Україна посіла 50-те місце серед 127 економік світу, піднявшись на шість позицій порівняно з 2016 роком (56-те місце). Згідно Глобального інноваційного індексу 2014, Україна знаходилась на 63 місці (у 2011 р. - на 60 місці серед 125 країн, у 2012 р. на 63 місці серед 125 країн, у 2013 р. на 71 місці серед 142 країн) [3]. Як бачимо, Україна, після провальних 90-х формально має певну позитивну динаміку даного показника. Bloomberg у статті «These Are the world's Most Innovative Economies» повідомляє, що у рейтингу 2017 року країн 3 найбільш інноваційною економікою Україна посіла 42-е місце, опустившись на одну позицію порівняно 3 попереднім роком. Згідно 3 рейтингом, обсяг коштів у відсотковому відношенні до ВВП, який Україна витрачає на дослідження і розробки має коефіцієнт 44; продуктивність - 50; присутність в економіці високотехнологічних компаній - 34; кількість зареєстрованих патентів i число дослідників - 27. Але на жаль, ці дані певною мірою такі ж маніпулятивні, як і українська статистика: вони не відображають реальну ефективність практичного запровадження інновацій саме для нашої економіки.

Згідно того ж дослідження Bloomberg (These Are the world's Most Innovative Economies) у 2017 p., на першому місці знову, як і 2016 р. опинилась Південна Корея [4]. Швеція піднялася на другу позицію, третє місце посіла Німеччина (2016-го року була на другому місці), четверте Швейцарія, Фінляндія закрила першу п'ятірку 2017 року. Швеція і Фінляндія піднялися вгору списку завдяки значному зростанню високотехнологічних фірм у країні. До першого десятка також потрапили Сінгапур (6 місце), Японія (7), Данія (8). США впали на одну позицію на 9 сходинку, у той час як Ізраїль піднявся на одну сходинку на 10 місце. Польща за рік піднялася 323 на 22 сходинку, а Угорщина 330 позиції піднялася на 27. Також, Естонія - на 33 місці, Словаччина - 36, Латвія - 39, Мальта - 40, а Казахстан 350 сходинки піднявся на 48. Видання зазначає, що Південна Корея очолює рейтинг завдяки найбільшим витратам на наукові дослідження i розробки, патентній активності, виробництву з доданою вартістю і рівню вищої освіти. Але ці дані про витрати на нововведення відображають реальні витрати на реальні нововведення, а не на віртуальні копії нововведень, як це не так рідко буває в Україні [1; 6].

Розглянемо економічні та організаційні параметри розвитку Південної Кореї та їх взаємозв'язок. На сьогоднішньому етапі глобального розвитку Республіка Корея (Південна Корея) є однією з найбільш економічно розвинених країн світу. Вона зуміла зайняти лідерські позиції в сферах суднобудування, машинобудування, виробництві телекомунікаційного обладнання, рідкокристалічних дисплеїв, напівпровідників тощо (до речі, усі ці напрямки у 1980 роках успішно розвивалися в УРСР). За станом на кінець 2017 p. показник GII (Глобальний інноваційний індекс) країни дорівнював 57,7, що відповідало 11 місцю в світовому рейтингу. Як свідчать статистичні дані, за період 2011-2017 pp. цей показник покращився на 5 позицій (рис. 1) [19; 20]. Необхідно зазначити, що значні досягнення останніх років, серед яких збільшення конкурентоспроможності (рис. 1), укладання великих міжнародних угод та започаткування великих інноваційно-інвестиційних проектів в різних галузях, були досягнуті завдяки цілеспрямованому створенню та успішному функціонуванню національної інноваційної системи (НIC) країни. Республіка Корея де- 


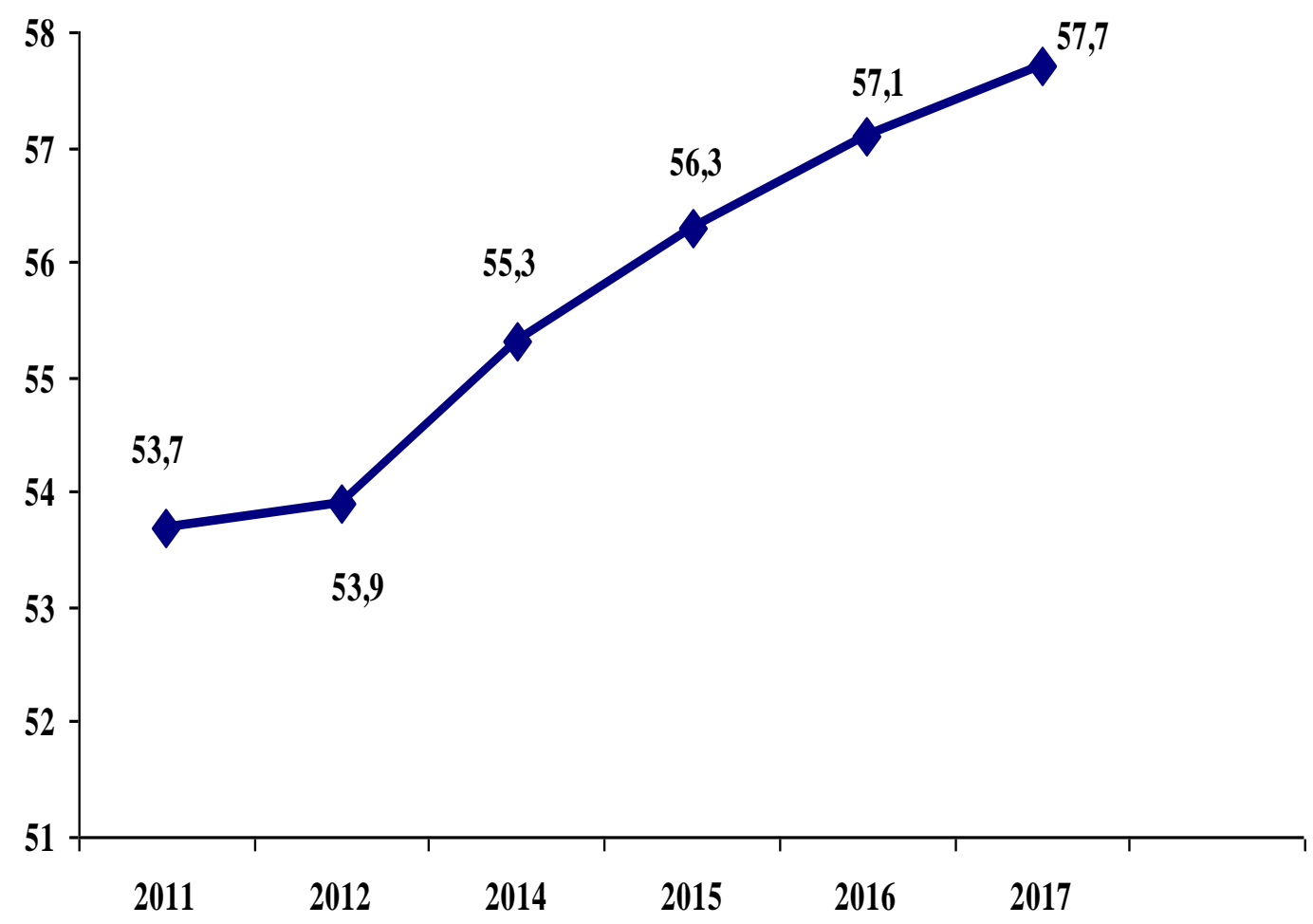

Рис. 1. Глобальний інноваційний індекс Республіки Корея за 2011-2017 рр. (за даними $[14 ; 15 ; 16 ; 17 ; 18 ; 19 ; 20])$

монструє позитивний досвід того, наскільки ефективною може бути чітко та професійно організована співпраця наукової спільноти, держави та бізнесу [12]. На нашу думку, успіх цієї країни в інноваційній сфері був реалізований завдяки ефективним, власними силами спроектованим перетворенням від аграрної економіки до інноваційної на базі власної

(незалежної від рекомендацій МВФ, інших міжнародних організацій тощо) промислової політики.

Високий рівень інноваційної системи Республіки Корея формувався протягом чотирьох етапів розвитку (табл. 1).

За даними табл. 1, за тридцять років економіка Південної Кореї зазнала успішних трансформацій. Їх позитивний зміст, великою мірою, забезпечений завдяки свідомому та ефективному впровадженню до основних галузей економіки досягнень науки, інновацій та технологій. Серед основних факторів успіху дослідники відмічають, зокрема: стратегічний курс уряду, постійно націлений на розширення зовнішніх зв'язків; промислову політику, орієнтовану на підтримку крупних підприємств(об'єднань); ефективну систему державних заходів, націлених на розвиток людських ресурсів. Аналіз джерел [5; 7; 13] свідчить, що на старті інноваційна стратегія Південної Кореї розвивалась із використанням, насамперед, зовнішніх джерел технологічних новацій, оскільки в країні був відсутній власний сучасний технологічний потенціал. Державна стратегія була націлена на: 1) сприяння трансферу іноземних технологій та їх ефективне використання на національному рівні; 2) розвиток

Таблищя 1

\section{Етапи формування національної інноваційної системи (НIC) РеспублікиКорея *}

\begin{tabular}{|c|c|c|}
\hline $\begin{array}{c}\text { № } \\
\text { п/п }\end{array}$ & Етап & Характеристика \\
\hline $\mathbf{1}$ & $\mathbf{2}$ & $\mathbf{3}$ \\
\hline $\mathbf{1}$ & $\begin{array}{c}\text { Період 1960-их рр. }- \\
\text { етап початку }\end{array}$ & $\begin{array}{c}\text { В } 1962 \text { р в Південній Кореї на урядовому рівні починається реалізація 1-го } \\
\text { плану економічного розвитку на п’ять років. Основна мета плану - посилення }\end{array}$ \\
\hline
\end{tabular}


Продовження табл.1

\begin{tabular}{|c|c|c|}
\hline $\begin{array}{c}\text { № } \\
\text { I/I/I }\end{array}$ & Етап & Характеристика \\
\hline 1 & 2 & 3 \\
\hline 1 & $\begin{array}{c}\text { створення нормативно- } \\
\text { правового та інсти- } \\
\text { туційного забезпече- } \\
\text { ння, програмування } \\
\text { розвитку інноваційної } \\
\text { економіки }\end{array}$ & $\begin{array}{l}\text { розвитку трудомістких експортно-орієнтованих галузей (виробництво одягу, } \\
\text { текстильних виробів, взуття). На даному етапі найважливішими є розвиток } \\
\text { імпортозамінних галузей промисловості та індустріалізація країни, інновації } \\
\text { не займають першочергову роль. } \\
\text { Створення Корейського інституту науки і технологій (the Korea Institute of } \\
\text { Science and Technology - KIST), Корейського провідного науково-технічного } \\
\text { iнституту (the Korea Advanced Institute of Science and Technology - KAIST), } \\
\text { Міністерства науки і технологій Республіки Корея (1967 р.) (цей орган влади } \\
\text { орієнтований на розробку і реалізацію державної науково-технічної політики) }\end{array}$ \\
\hline 2 & $\begin{array}{c}\text { Період 1970-х - } \\
\text { початку 1980-х рр.-- } \\
\text { етап появи крупних } \\
\text { ФПГ, зміцнення } \\
\text { якості освіти, } \\
\text { інституційного } \\
\text { забезпечення }\end{array}$ & $\begin{array}{l}\text { Поява пріоритетних галузей промисловості (період 1970-х-1980-х рр.) - } \\
\text { суднобудування, нафтохімія, споживча електроніка, автомобілебудування. } \\
\text { Результат такої політики - виникнення крупних фінансово-промислових груп } \\
\text { (ФПГ) (чебол). Чеболам в стратегічно важливих галузях промисловості } \\
\text { надавалась підтримка в сфері залучення іноземних інвестицій. } \\
\text { Інноваційний розвиток не займає ключових позицій в економічній політиці, } \\
\text { але розширюється система вищої освіти, збільшується фінансування урядом } \\
\text { дослідних інститутів, посилюється участь наукової спільноти країни в } \\
\text { кращих освітніх програмах закордоном, впроваджена програма щодо } \\
\text { повернення наукового людського потенціалу з інших країн }\end{array}$ \\
\hline 3 & $\begin{array}{c}\text { 1980-і рр. - період } \\
\text { стрімкого розвитку } \\
\text { національної } \\
\text { інноваційної системи, } \\
\text { масштабного } \\
\text { інвестування в } \\
\text { розвиток НДДКР }\end{array}$ & $\begin{array}{l}\text { Початок Національної програми НДДКР спільно з ініціативами, націленими } \\
\text { на підтримку приватних компаній у розвитку високих технологій (1982 р.). } \\
\text { Державне сприяння розвитку високотехнологічних галузей, зокрема, } \\
\text { виробництва напівпровідників (середина 1980-х рр.).Період значних } \\
\text { фінансових інвестицій в формування наукових та технологічних парків в } \\
\text { країні. Поступове зростання частки приватних інвестицій над державними. В } \\
\text { перше десятиріччя ХХІ ст. показник приватних інвестицій в загальному } \\
\text { складі інвестицій в НДДКР склав } 80 \% \text {. } \\
\text { Для цього на державному рівні створювались привабливі умови інноваційної } \\
\text { діяльності, зокрема, запроваджувались податкові стимули для здійснення } \\
\text { імпорту іноземних технологій та розвитку НДДКР }\end{array}$ \\
\hline 4 & $\begin{array}{c}\text { 1990-х рр. - до } 2017 \\
\text { р. - період реструкту- } \\
\text { ризаційних заходів, } \\
\text { націлених на підвище- } \\
\text { ння ефективності кон- } \\
\text { курентного середови- } \\
\text { ща інноваційної сфе- } \\
\text { ри, прийняття } \\
\text { програм та ініціатив, } \\
\text { орієнтованих на } \\
\text { забезпечення } \\
\text { зростання рівня } \\
\text { інновацій країни }\end{array}$ & $\begin{array}{l}\text { Початок реструктуризації чебол з відповідним виокремленням непрофільних } \\
\text { виробництв (з } 1993 \text { р.). На рівні Міністерства науки і технологій ініційовано } \\
\text { прийняття спеціального закону про наукові і технологічні інновації, } \\
\text { сформовано план наукових і технологічних інновацій (на 1997-2002 рр.), } \\
\text { розроблено Національний проект високих технологій в області НДДКР - НАN } \\
\text { (Нighly Advanced National Project) і Творчу дослідницьку ініціативу, а також } \\
\text { низку інших програм. Реструктуризація державних дослідницьких центрів } \\
\text { (1998 р.), націлена на формування ефективного конкурентного середовища. } \\
\text { Прийняття «Довгострокових прогнозів розвитку науки і технологій до } 2025 \\
\text { p.» (the Long-term Vision for Science and Тесhnology Development toward 2025) } \\
\text { (199 p.). } \\
\text { Схвалення «Базових планів науки і технологій» (Science and Technology Basic } \\
\text { Plan) (2003 р., } 2008 \text { р., } 2013 \text { р.) }\end{array}$ \\
\hline
\end{tabular}

на цій базі власного інноваційного потенціалу для більш успішного застосування та вдосконалення технологій. Що стосується часового простору, то аналіз фактів свідчить: успіх країни в інноваційній сфері був досягнутий завдяки Урядовій стратегії перетворення Південної Кореї від аграрної економіки до інноваційнопромислової впродовж 4-ох етапів.
Стратегія розвитку інноваційної компоненти бізнесу Південної Кореї змушена була на першому етапі базуватися на ідеї залучення зовнішніх джерел технологій: на цьому етапі в країні був відсутній власний технологічний потенціал. Але з самого першого етапу державна стратегія розвитку національного бізнесу в Південній Кореї була націлена на сприяння 
залучення в національний бізнес, насамперед, передових іноземних технологій та їх ефективне використання на загальнонаціональному рівні. Одразу було закладено орієнтир на розвиток інноваційного потенціалу для більш успішного застосування та вдосконалення технологій [5]. На першому етапі використовувалась пряма форма державного регулювання цієї сфери. Зокрема, через адміністративно-правові бар'єри: заходи 3 обмеження права власності, встановлення вимог стосовно передачі технологій і 3 експорту продукції, заходи щодо репатріації прибутку. Внаслідок жорсткості такого підходу країна не змогла спочатку ефективно використати прямі іноземні інвестиції для реалізації процесу трансферу технологій для розвитку високотехнологічного вітчизняного бізнесу [7]. На урядовому рівні для цього не було стимулів, а навпаки створювались адміністративно-правові перешкоди. Слід відмітити, що незважаючи на благородні патріотичні цілі, пряме державне втручання у формі впровадження валютного контролю на першому етапі постало бар'єром для трансферу технологій за допомогою ліцензування. Пояснюється це тим, що на цьому етапі уряд обмежував придбання іноземних ліцензій, оскільки країна в 1960-х рр. ще не мала фінансових можливостей для їх прямого придбання $[11 ; 13 ; 21]$. Було необхідно укладати довгострокові фінансові зобов'язання, що урядовими стратегами розвитку держави не вважалось прийнятним. Це привело до гальмування розвитку. Але державне керівництво
Південної Кореї швидко зробило із прорахунків першого етапу висновки і на наступних етапах, у якості альтернативного варіанту, було обрано гнучку стратегію залучення прямих іноземних інвестицій у виробничий сектор. На цій основі планомірно здійснювався масштабний імпорт високотехнологічних товарів для «дослідження» останніх стосовно можливого запозичення (купівлі) необхідних технологій, паралельно реалізувались проекти із будівництва заводів силами провідних іноземних компаній. Урядами Південної Кореї на другому та наступних етапах вже усвідомлено, на основі експертних оцінок та розрахунків, визначалися ключові галузі інвестування, перелік та склад підприємців, яким надавались нові інвестиційно-інноваційні проекти. Як показує досвід еволюції бізнесу Південної Кореї, найбільш успішні та економічно-патріотичні з вказаних підприємців, протягом певного часу очолили та стали власниками чеболів (національних ФПГ). В табл. 2 наведено основні джерела трансферу технологій в Республіці Корея в 1962-1981 pp.

3 даних, наведених у табл. 2 видно, що обраний Урядом варіант розвитку трансферу технологій в Південній Кореї мав найбільшу результативність через відсутність обмежувальних заходів порівняно 3 двома іншими можливими варіантами. Незважаючи на суттєвий директивний вплив неринкової природи, уряд зміг убезпечити країну в 1960-1980-і рр. від збільшення суми довгострокових фінансових зобов'язань перед зовнішніми інвесторами.

Основні джерела трансферу технологій в Республіці Корея в 1962-1981 рр. (за матеріалами [21])

\begin{tabular}{|c|c|c|c|}
\hline $\begin{array}{c}\text { Період трансферу } \\
\text { технологій в Південній } \\
\text { Кореї }\end{array}$ & $\begin{array}{c}\text { Обсяг } \\
\text { використання } \\
\text { прямих іноземних } \\
\text { інвестицій, млрд. } \\
\text { дол. США }\end{array}$ & $\begin{array}{c}\text { Обсяг } \\
\text { використання } \\
\text { зовнішнього } \\
\text { ліцензування, млрд. } \\
\text { дол. США }\end{array}$ & $\begin{array}{c}\text { Обсяг державного } \\
\text { інвестування в товари } \\
\text { прослового призначення в } \\
\text { цілях вивчення та } \\
\text { запозичення технологій, } \\
\text { млрд. дол. США }\end{array}$ \\
\hline $\mathbf{1}$ & $\mathbf{2}$ & $\mathbf{3}$ & $\mathbf{4}$ \\
\hline Період 1962-1966 pp. & 0,0454 & 0,008 & 0,316 \\
\hline Період 1967-1971 pp. & 0,2186 & 0,0163 & 2,54 \\
\hline Період 1972-1976 pp. & 0,8794 & 0,0966 & 8,84 \\
\hline Період 1977-1981 pp. & 0,7206 & 0,4514 & 27,98 \\
\hline
\end{tabular}

Внаслідок такої політики в Південній Кореї відбувався стрімкий розвиток в тих основних ключових галузях, які визначались на державному рівні. Це, в результаті, забезпечило успіх економіки у цілому. Поступово була створена ефективна інституційна база організації управління інноваційним розвитком. Країна досягла значних успіхів у підвищенні 
конкурентоспроможності власної продукції, технологій, які стали конкурентними на зовнішніх ринках. Як вказують дослідники [7], незважаючи на поступову певну лібералізацію державного регулювання, в Південній Кореї на сьогоднішній день існує така система державноприватного партнерства (держава - місцевий бізнес (національні приватні інвестиції) іноземний бізнес (іноземні інвестиціі)) в сфері трансферу технологій, яка за умов дотримання інтересів усіх учасників передбачає, що єдиним головним розпорядником змісту інноваційного розвитку є держава, рішення якої є обов' язковими для інших учасників.

Ефективна державна політика в сфері трансферу технологій забезпечила успіх Республіки Корея не тільки на внутрішньому, але i на зовнішніх ринках. Результатом професійного та комплексного урядового регулювання, внаслідок активної безпосередньої державної участі в управлінні стало те, що країна без модерного технологічного потенціалу у 80-90 рр. сьогодні стала провідним експортером інноваційних технологій. У таблиці 3 представлено обсяги надходжень в бюджет Південної Кореї від експорту ліцензій та патентів за період 2000-2015 pp.Дані табл. 3 свідчать, що за досліджуваний період відбулось зростання вказаного показника на 398\% (37675,57 млн. дол. США). Як бачимо, кожен рік відбувалось лише збільшення обсягів бюджетних доходів від експорту ліцензій та патентів, що, у свою чергу, свідчить про ефективність державного регулювання у цій cфepi.

Таблиця 3

Надходження в бюджет Південної Кореї доходів від експорту ліцензій і патентів та обсяги інвестицій в вищу освіту за період 2000-2015 рр.*

\begin{tabular}{|l|c|c|c|c|c|c|c|c|c|}
\hline \multicolumn{1}{|c|}{ Показники } & \multicolumn{7}{c|}{ Роки } \\
\cline { 2 - 10 } & $\mathbf{2 0 0 0}$ & $\mathbf{2 0 0 2}$ & $\mathbf{2 0 0 4}$ & $\mathbf{2 0 0 6}$ & $\mathbf{2 0 0 8}$ & $\mathbf{2 0 1 0}$ & $\mathbf{2 0 1 2}$ & $\mathbf{2 0 1 4}$ & $\mathbf{2 0 1 5}$ \\
\hline $\begin{array}{l}\text { Надходження в бюджет } \\
\text { доходів від експорту } \\
\begin{array}{l}\text { ліцензій та патентів (млн. } \\
\text { дол. США) }\end{array}\end{array}$ & 9450 & 11957 & 15685 & 19469 & 23961 & 30230 & 39833 & 45944 & 47126 \\
\hline $\begin{array}{l}\text { Обсяги інвестицій у вищу } \\
\text { освіту (млн. дол. США) }\end{array}$ & 1439 & 1656 & 2057 & 2508 & 3543 & 4373 & 4863 & 5314 & 5528 \\
\hline
\end{tabular}

*(складено за статистичними даними ОЕСР $[14 ; 15 ; 16 ; 17 ; 18 ; 19 ; 20])$

Вагома роль у розвитку трансферу технологій та становлення інноваційної економіки належить також науковій спільності. Проте слід відмітити, що держава приділяе увагу рівню освіти науковців та дослідників. Постійне вдосконалення вищої освіти, підготовка таких кадрів та окремих винахідників в наукових установах, які б були орієнтовані на високотехнологічні розробки, що користуються попитом, $є$ національним пріоритетом Південної Кореї. Це пояснює вагомий рівень інвестицій у вищу освіту в країні та високу віддачу освіти та науки Південної Кореї для їі економіки. У табл. 3 наведено також дані про обсяги інвестицій в вищу освіту Південної Кореї за період 2000-2015 pp. За даними, наведеними у табл. 3, можемо констатувати зростання вказаного показника за останні п'ять років на $26 \%$, що є свідченням того, що підвищення рівня вищої освіти залишається вагомим пріоритетом уряду Південної Кореї. Для порівняння асигнування 3 бюджету України на вищу освіту за той же період знизилися з 3,5\% ВВП у 2009 р. до 2,7\% у 2014-му, і 2,3\% ВВП у 2016-му. I це при низьких обсягах офіційного
ВВП. Можна відмітити, що відсутність інвестицій до цієї сфери не сприяє виникненню потужної інноваційної галузі, i навіть не дозволяє утримувати промисловий розвиток на сталому рівні.

Необхідно визнати, що без достатніх підстав та умов у деіндустріалізованій та технологічно, освітньо, ідеологічно, інформаційно, інтелектуально деградованій країні не виникнуть «3 пустоти» інноваційні кластери та інноваційні галузі. Адже будь-яким практичним інноваціям передує фаза НДДКР (або за міжнародною абревіатурою - R\&D). Саме ця сфера та фаза стає сьогодні ареною найгострішої конкурентної боротьби держав і корпорацій. I на цьому етапі наука виконує свою роль активної продуктивної сили через іï глибоку інтеграцію 3 потребами i можливостями конкретного виробництва.

Важливою економічною характеристикою $\mathrm{R} \& \mathrm{D}$ є їхня спроможність до мультиплікативних ефектів в економіці: дослідження та розробки, проведені в одній галузі, впливають на показники інших галузей та економіки в цілому. Міжгалузеві $\mathrm{R} \& \mathrm{D}$ ефекти виникають завдяки різним каналам 
передачі, основними серед яких $є$ торгівля товарами та послугами, обмін патентами, використання інновацій [2]. На жаль, в Україні майже зовсім знищена мережа прикладних науково-дослідних установ, а ті, що залишилися стали не галузевими, а вузько-відомчими та практично не дають ніяких конкурентоспроможних результатів.

Сучасна нормативно-правова база стосовно науково-технічної та інноваційної діяльності налічує близько 200 документів. Зокрема, національне інноваційне законодавство включає норми Конституції України, Господарського кодексу, Закону України «Про пріоритетні напрями розвитку інноваційної діяльності в Україні», Закону України «Про інноваційну діяльність», Закону України «Про інвестиційну діяльність», Закону України «Про спеціальний режим інноваційної діяльності технологічних парків», Закону України «Про наукову і науковотехнічну діяльність», Закон України «Про затвердження загальнодержавної комплексної програми розвитку високих наукоємних технологій» та інших нормативно-правових актів, які визначають правові, економічні та організаційні засади державного регулювання інноваційної діяльності в Україні, встановлюють форми стимулювання державою інноваційних процесів і спрямовані на підтримку розвитку економіки України інноваційним шляхом.

Задля створення бази для розвитку новітніх технологій та успішної побудови постіндустріальної економіки маленькими, але цілеспрямованими кроками Україні потрібно відновлювати-створювати, насамперед, свій науковий і промисловий потенціал. Діада «наукапромисловість» - це асинхронний мотор прогресу. Його запустити по-справжньому можливо лише на основі власної промислової політики, чітко сформульованої відповідальним Урядом, усвідомленої великим бізнесом та прийнятої як експертним товариством, так i громадянським суспільством. Але таку власну промислову політику, яка служить не суто іноземним капіталістам та/або вітчизняним олігархам вже не так просто зробити: ми вже потрапили до пастки подвійної інверсної спіралі кризового розвитку, що поволі стягується до пастки тупикової колії.

Наука та вітчизняні технології перетворилися на віртуальну реальність. Це на одних підприємствах призвело до «натуральної» поступової деградації технологічного рівня виробництва, а на інших, до того, що їх в минулому високий рівень та якість виробництва випередили іноземні компанії. Вітчизняні промислові підприємства та конструкторські бюро, які залишилися і мають напрацювання, ще конкурентні на глобальному ринку, на жаль, знаходяться у жалюгідному фінансовому стані, оскільки не мають ніякої реальної підтримки 3 боку держави (ми не враховуємо аутсорсинг та аутстафинг у сфері інформаційних технологій, оскільки вони збагачують в основному іноземні компаніі). Але не тільки фінансові негаразди та ресурсні обмеження призвели до деградації промислового потенціалу України. Невдалі та неефективні організаційні зміни в секторах та структурах економіки та популістськоспоживацькі політико-економічні реформи, орієнтовані на запити олігархів (субсидійний капіталізм), вплинули на знищення основи промислової політики в Україні. Паралельно 3 цим відбувалося підміна розуміння суті інновацій як результатів відповідальної промислової політики та державної стратегії на очікування спонтанних «подарунків розвитку ринку».

А ситуація 3 подарунками та самоорганізацєю ринку, інноваціями та новаціями набагато складніша. Як свідчить досвід розвитку Південної Кореї, нововведення та інновації - це динамічні грані єдиного процесу технологічного розвитку можливостей виробників та потреб i смаків споживачів. Інновація як одна із граней дає можливість розв'язати накопичені проблеми та складні виробничі завдання, а 3 іншого боку інноваційне підприємництво грунтується на пошуку нових креативних шляхів розвитку пропозиції акторів бізнесу, що кардинально відрізняється від репродуктивного, класичного виду підприємницької діяльності. Це може бути, як створення нової продукції, технології, матеріалів, так і створення або виявлення нових ринків, форм управління або ж нової інноваційноорієнтованої структури підприємництва. Але завжди процес пошуковий та плановопошуковий. Спостереження за рівнем інноваційного розвитку української економіки показує, що перед країною стоїть важлива проблема як якісного підвищення інноваційної активності підприємницького сектора, так i створення ефективних механізмів комерціалізації результатів інтелектуальної діяльності. Ця діада може стати в майбутньому грунтом розвитку національної інноваційної системи (НIC). Проте, НIC зможе розгорнутися тільки внаслідок здійснення програмної послідовності дієвих кроків організаційних перетворень релевантних суспільно-державних інститутів (НАНУ, галузеві AH, галузеві науково-дослідні організаціі, підрозділи системи МОН, самодіяльні науковотехнічні товариства, агентства розвитку тощо), координованих відповідальним Урядом. Адже ці кроки іманентно структурно-функціонально 
складні в умовах трансформаційної наздоганяючої економіки.

Зміст цієї складності, на нашу думку, повинен бути прийнятим, усвідомленим на урядовому, підприємницькому рівні, рівні громадянського суспільства. Зокрема, на концептуальнопрограмному рівні повинно бути визначено гостру необхідність системного контролю співпраці уряду та підприємницького сектору в рамках розвитку, реалізації основних засад інноваційної політики. Треба практично визнати, що основним завданням промислового розвитку $€$ одночасний розвиток змістового стержня та інфраструктури інноваційного підприємництва. Тут роль ініціатив Уряду для успішної інтеграції вітчизняної економіки у світові процеси зумовлені Четвертою індустріальною революцією повинна стати сьогодні визначальною.

Ефективність здійснення інноваційного процесу на старті впровадження, як свідчить досвід Південної Кореї, визначається ефективністю такого його важливого комерційного та управлінського інструменту як трансфер технологій. На нашу думку, Уряду України доцільно активізувати трансфер технологій в пріоритетних секторах промисловості. Адже трансфер технологій є одним 3 провідних напрямів науково-технічної політики всіх розвинених країн світу i забезпечує їх прискорений розвиток. Особливість трансферу технологій полягає в необхідності поєднати дві абсолютно несхожі за мотиваціями області: науку i бізнес. Основа комерційного успіху трансферу технологій - це правове і фінансове забезпечення науково-інноваційної сфери. Завданням уряду є створення такого організаційного, правового та фінансово-мотиваційного комплексу, основною метою якого буде формування наукомістких високотехнологічних конкурентоспроможних галузей. Це дозволяють національній економіці стати менш залежною від експортно-сировинної спрямованості. Незважаючи на затяжну трансформаційну кризу, Україна ще у 2018 р. має перспективи для старту інноваційного розвитку економіки. Для держави є перспективи (за умов залучення потенціалу всіх верств суспільства, починаючи 3 найбагатших) стати повноправним конкурентом-партнером на світовому ринку інновацій і високих технологій. Ця мета досяжна лише при комплексному підході до вирішення поставлених завдань, а також при наявності не тільки політичної волі, а й послідовних програмних дій Уряду. Досягнення такого результату потребує реформованої інституціональної інфраструктури інноваційного розвитку України [3].
В Україні інституціональна структура інноваційного розвитку представлена Міністерством освіти i науки України, Міністерством економічного розвитку і торгівлі України, Міністерством промислової політики України, Національною академією наук України, Національною радою інноваційного розвитку, галузевими інститутами й академіями. Недосконалість такої горизонтальної інституціональної структури не мотивованої для отримання спільного результату очевидна. Вона, зокрема, полягає в розподіленні суто контролюючих обов'язків між кількома міністерствами, що виражається в деякому їх дублюванні й відсутності єдиного керівного органу управління інноваційним розвитком. Така «контролююча» система департаментів, комісій міжвідомчих комітетів підкріплюється недосконалістю законодавства в інноваційній сфері, не сприяє розвитку інноваційної діяльності. Покладання на Міністерство освіти i науки України основної функції головного координатора інноваційного розвитку $\epsilon$ неефективним, оскільки воно далеко від потреб промисловості. Внаслідок, переважна більшість інноваційних наукових досягнень, які виконані у вітчизняних ВН3 не знаходять практичного втілення, а «зависають» на завершальній стадії розробки, або ж у кращому випадку знаходять втілення за кордоном, не приносячи економічної вигоди Україні. Як правило, таким шляхом ми втрачаємо ще i не отриману вигоду майбутніх періодів: втрачаємо найбільш талановитих науковців. Вони не знаходять можливості в Україні запровадити власні ідеї та інноваційні розробки, але дуже швидко реалізують свої ідеї та розробки як тільки отримують підтримку за межами України. Такий «подвійний зашморг» все сильніше затягується навколо стану вітчизняного науково-інноваційного підприємництва та русла інноваційного майбутнього нашої держави.

На основі проведеного вище аналізу ми висловлюємо тезу про доцільність створення в Україні спеціалізованого міністерства інноваційного розвитку та промислової політики. Адже для олігархізованої України створення економіки інноваційного змісту залежить від ефективності промислової політики Уряду та ініціативності функціонерів Уряду. Але практична результативність такого міністерства виникне лише при дотриманні таких імперативів: 1) відповідальність за реалізацію державної стратегічної інноваційної політики; 2) пошук програмних компонент інноваційної політики проривного типу; 3) дієве оперативно-тактичне державне втручання у засоби стимулювання прогресивної структурної перебудови економіки 
та системи вищої освіти; 4) механізм управління цією інституцією повинен бути орієнтований на власну промислову політику, а не на «Болонський процес» реформування сфер вищої освіти, науки та інноваційного підприємництва; 6) оцінка кошторису витрат на менеджмент міністерства повинна здійснюватися на основі співвідношення доходів від експорту патентів та ліцензій до витрат на імпорт патентів та ліцензій.

Висновки та перспективи подальших досліджень. Зупинити деградацію промислового потенціалу України можна лише формуючи належним чином інноваційну діяльність, що потребує нового налаштування провідних галузей економіки, а також науки та освіти. Пошук шляхів виходу 3 кризи повинен бути багатовекторним, але як правило, найбільш безпечним $\epsilon$ перевірений шлях.

Для України найбільш прийнятним $\epsilon$ застосування досвіду Південної Кореї, оскільки вона виробила специфічний ефективний механізм державного регулювання трансферу інноваційних технологій, який передбачає використання i прямого, i непрямого впливу держави. Незважаючи на достатньо явне директивне регулювання цієї сфери, Південна Корея займає лідерські світові позиції в галузі інноваційного розвитку та передавання технологій.

Впровадження корейського досвіду $\mathrm{y}$ вітчизняну економіку передбачає необхідність фундаментальної реконструкції всіх сфер промисловості, вищої освіти, інституційного забезпечення тощо. Доведено, що для досягнення цілей випереджального інноваційного розвитку Україні потрібен жорсткий контроль за ефективністю використання бюджетних коштів, що виділяються для запровадження трансферту технологій, або ж фінансування власних інноваційних розробок. Для України, Уряд якої вкотре заявляе про намагання відродити промисловість на якісно новому рівні, запровадження практики Південної Кореї сьогодні ще посильна справа, але вона не терпить відкладання та перенесень на наступні періоди часу. Затяжна кризова ситуація не може існувати довго: результати форсайтингових досліджень показали, що поглиблення кризи може призвести до втрати Україною не тільки економічної, але i політичної незалежності.

\section{ПЕРЕЛІК ВИКОРИСТАНИХ ДЖЕРЕЛ}

1. В Раде заявили, что скандальная правка «под Ахметова» таки принята. Дата оновлення: 17.08.2018. https://www.pravda.com.ua/rus/news/2018/07/17/7186602/ (дата звернення: 17.08.2018).

2. Вишневецький В.П., Збаразська Л.О., Заніздра М.Ю. Національна модель неоіндустріального розвитку України. К., 2016. 519 с.

3. Гринько Т. В. Інноваційний розвиток України: тенденції та проблеми. Технологический аудит и резервы производства. 2013. № 1/3(9). С. 17-20

4. Економіка України опустилася у глобальному рейтингу інновацій. Bloomberg. Інфографіка. Дата оновлення: 17.08.2018. https://tsn.ua/groshi/ekonomika-ukrayini-opustilasya-u-globalnomu-reytingu-innovaciybloomberg-infografika-864394.html (дата звернення: 17.08.2018).

5. Зиновьева Е., Мулловский Н. Опыт Республики Корея в области инновационного развития. Право и управление. XXI век. 2015. № 3(36). С. 142-147

6. 3 нового року «зелений тариф» для Клюєва буде більший ніж за часи Януковича. Дата оновлення: 17.08.2018.

https://censor.net.ua/blogs/1102972/z_novogo_roku_quotzeleniyi_tarifquot_dlya_klyuva_bude_blshiyi_nj_za_chasi_ya nukovicha (дата звернення: 17.08.2018).

7. Колотырина Е.А. Особенности становления инновационной системы Республики Корея. Вестник Российского университета дружбы народов. 2015. С. 96-104

8. Сіденко І. та ін. Структурні трансформації у світовій економіці: виклики для України. К: Заповіт, 2017. $182 \mathrm{c}$.

9. Уряд планує приватизувати близько 900 підприємств та ліквідувати більше 1000. Дата оновлення: 17.08.2018. http://lesovod.blogspot.com/2017/07/900-1.html (дата звернення: 17.08.2018).

10. Черленяк I.І., Машіко К.С. 25 років модерному українському капіталізму. Науковий вісник Ужгородського університету : серія: Економіка; збірник наукових праць. 2016. № 2 (48). С. 47-55.

11. Chung, Sungchul. Innovation, Competitiveness, and Growth: Korean Experience. Annual World Bank Conference on Development Economics. 2010. pp. 333-357.

12. Main Science and Technology Indicators. Дата оновлення: 17.08.2018. https://stats.oecd.org/Index.aspx?DataSetCode=MSTI_PUB (дата звернення: 17.08.2018).

13. Sam Ock Park. Regional innovation strategies in the knowledge-based economy. Geojournal. 2001. pp. 29-38. 
14. The Global Innovation Index 2014. The Human Factor in Innovation. Дата оновлення: 17.08.2018. http://www.globalinnovation index.org/content.aspx?page=gii-full-report-2014 (дата звернення: 17.08.2018).

15. The Global Innovation Index 2014. The Human Factor in Innovation Дата оновлення: 17.08.2018. https://www.globalinnovationindex.org/userfiles/file/reportpdf/GII-2014-v5.pdf (дата звернення: 17.08.2018).
16. The
Global
Innovation
Index
2013.
Дата
оновлення:
17.08.2018.

http://www.globalinnovationindex.org/userfiles/file/reportpdf/GII-2013.pdf (дата звернення: 17.08.2018).

17. The Global Innovation Index 2012. Дата оновлення: 17.08 .2018$.

http://www.globalinnovationindex.org/userfiles/file/GII-2012-Report.pdf (дата звернення: 17.08.2018).

18. The Global Innovation Index 2011. Дата оновлення: 17.08 .2018$. https://www.globalinnovationindex.org/userfiles/file/GII-2011_Report.pdf (дата звернення: 17.08.2018).

19. The Global Innovation Index. Дата оновлення: 17.08.2018. https://www.globalinnovationindex.org/gii-2017report\# (дата звернення: 17.08.2018).

20. The Global Innovation Index Korea, Republic of (2017). Дата оновлення: 17.08.2018. https://www.globalinnovationindex.org/gii-2017-report\# (дата звернення: 17.08.2018).

21. Whang, In-Joung. The role of government in Korea's industrial development. Seoul: Korea Development Institute, $1985.30 \mathrm{p}$.

\section{REFERENCES}

1. Ukrajinsjka pravda (2018) V Rade zajavyly, chto skandaljnaja pravka «pod Akhmetova» taky prynjata [In the parliament they said that the scandalous amendment "under Akhmetov" was still adopted] Available at: https://www.pravda.com.ua/rus/news/2018/07/17/7186602/ (accessed 17 August 2018)

2. Vyshnevecjkyj V.P., Zbarazsjka L.O., Zanizdra M.Ju. (2016) Nacionaljna modelj neoindustrialjnogho rozvytku Ukrajiny [National model of neoindustrial development of Ukraine]. K. (in Ukrainian)

3. Ghrynjko T. V. (2013) Innovacijnyj rozvytok Ukrajiny: tendenciji ta problemy [Innovative development of Ukraine: trends and problems]. Tekhnologicheskiy audit i rezervy proizvodstva, no. № 1/3(9), pp. 17-20

4. TSN (2018) Ekonomika Ukrajiny opustylasja u ghlobaljnomu rejtynghu innovacij. Bloomberg. Infoghrafika [Ukraine's economy has fallen in the global ranking of innovations. Bloomberg Infographics] Available at: https://tsn.ua/groshi/ekonomika-ukrayini-opustilasya-u-globalnomu-reytingu-innovaciy-bloomberg-infografika864394.html (accessed 17 August 2018)

5. Zinoveva Ye., Mullovskiy N. (2015) Opyt Respubliki Koreya v oblasti innovatsionnogo razvitiya [Experience of the Republic of Korea in the field of innovation development]. Pravo i upravlenie. KhKhI vek, no. 3(36), pp. 142-147

6. Cenzor.net (2018) Z novogho roku «zelenyj taryf» dlja Kljujeva bude biljshyj nizh za chasy Janukovycha [From the new year, the "green tariff" for Klyuyev will be higher than Yanukovych's time] Available at: https://censor.net.ua/blogs/1102972/z_novogo_roku_quotzeleniyi_tarifquot_dlya_klyuva_bude_blshiyi_nj_za_chasi_ya nukovicha (accessed 17 August 2018)

7. Kolotyrina Ye.A. (2015) Osobennosti stanovleniya innovatsionnoy sistemy Respubliki Koreya [Features of the formation of the innovation system of the Republic of Korea]. Vestnik Rossiyskogo universiteta druzhby narodov, pp. 96-104

8. Sidenko I. (2017) Strukturni transformaciji u svitovij ekonomici: vyklyky dlja Ukrajiny [Structural Transformations in the World Economy: Challenges for Ukraine]. K: Zapovit. (in Ukrainian)

9. Lisivnyk (2017) Urjad planuje pryvatyzuvaty blyzjko 900 pidpryjemstv ta likviduvaty biljshe 1000 [The government plans to privatize about 900 enterprises and eliminate more than 1,000] Available at: http://lesovod.blogspot.com/2017/07/900-1.html (accessed 17 August 2018)

10. Cherlenjak I.I., Mashiko K.S. (2016) 25 rokiv modernomu ukrajinsjkomu kapitalizmu [25 years of modern Ukrainian capitalism]. Naukovyj visnyk Uzhghorodsjkogho universytetu: serija: Ekonomika; zbirnyk naukovykh pracj, no. № 2 (48), pp. 47-55.

11. Chung, Sungchul (2010). Innovation, Competitiveness, and Growth: Korean Experience. Annual World Bank Conference on Development Economics, pp. 333-357.

12. OECD.Stat (2018) Main Science and Technology Indicators. Available at: https://stats.oecd.org/Index.aspx?DataSetCode=MSTI_PUB (accessed 17 August 2018)

13. Sam Ock Park (2001). Regional innovation strategies in the knowledge-based economy. Geojournal, pp. 29-38.

14. The Global Innovation Index (2014) The Global Innovation Index 2014. The Human Factor in Innovation. Available at: http://www.globalinnovation index.org/content.aspx?page=gii-full-report-2014 (accessed 17 August 2018)

15. The Global Innovation Index (2014) The Global Innovation Index 2014. The Human Factor in Innovation. Available at: https://www.globalinnovationindex.org/userfiles/file/reportpdf/GII-2014-v5.pdf (accessed 17 August 2018)

16. The Global Innovation Index (2013) The Global Innovation Index 2013. Available at: http://www.globalinnovationindex.org/userfiles/file/reportpdf/GII-2013.pdf (accessed 17 August 2018) 
17. The Global Innovation Index (2012) The Global Innovation Index 2012. Available at: http://www.globalinnovationindex.org/userfiles/file/GII-2012-Report.pdf (accessed 17 August 2018)

18. The Global Innovation Index (2011) The Global Innovation Index 2011. Available at: https://www.globalinnovationindex.org/userfiles/file/GII-2011_Report.pdf (accessed 17 August 2018)

19. The Global Innovation Index (2017) The Global Innovation Index. Available at: https://www.globalinnovationindex.org/gii-2017-report\# (accessed 17 August 2018)

20. The Global Innovation Index (2017) The Global Innovation Index Korea, Republic of (2017). Available at: https://www.globalinnovationindex.org/gii-2017-report\# (accessed 17 August 2018)

21. Whang, In-Joung (1985). The role of government in Korea's industrial development. Seoul: Korea Development Institute. (in Korea)

Одержано 22.08.2018 p. 